\title{
Community structure, life histories and secondary production of stoneflies in two small mountain streams with different degree of forest cover
}

\author{
Pavel BERACKO, ${ }^{*}$ Andrea KUŠNÍROVÁ, Michaela PARTLOVÁ, Jana CICEKOVÁ \\ Department of Ecology, Faculty of Natural Sciences, Comenius University, B-2 Mlynská Dolina, SK-842 15, Bratislava, Slovakia \\ *Corresponding author: beracko@fns.uniba.sk
}

\begin{abstract}
Our study examines community structure and nymphal biology (life cycles and secondary production) of stoneflies in two adjacent mountain streams with different degree of forest cover in the Prosiečanka River Basin (Chočské Vrchy Mts., West Carpathians). One of the streams has non-forested catchment, converted to meadows and pastures, while the other one has catchment with $60 \%$ covered by spruce forest. Differences in forest cover and in thermal regime of the streams were reflected by the difference of stonefly communities at their structural and functional level. Species Nemoura cinerea and Leuctra aurita created stonefly assemblage in non-forested stream, whereas Nemoura cinerea also occurred in naturally forested stream together with species Leuctra armata, Leuctra nigra, Leuctra prima, Siphonoperla neglecta and Arcynopteryx dichroa. All examined species had maximally annual life cycle and in eudominant species Nemoura cinerea one month shift was found in nymphal hatching and adult emergence between streams. Total secondary production of stoneflies in undisturbed stream (126.46 $\mathrm{mg} \mathrm{DW} \mathrm{m}^{-2} \mathrm{y}^{-1}$ ) was more than two times higher than the production in non-forested stream $\left(47.39 \mathrm{mg} \mathrm{DW} \mathrm{m}^{-2} \mathrm{y}^{-1}\right)$.
\end{abstract}

Key words: Deforestation; Plecoptera; life cycle; secondary production; small stream.

Received: May 2015. Accepted: October 2015.

\section{INTRODUCTION}

Macroinvertebrates are a key component of freshwater food-webs, participating in matter and energy flow through aquatic ecosystem (Covich et al., 1999; Wallace and Webster, 1996). The functional role of benthic populations in the trophic dynamics of any aquatic ecosystem reflects on one hand the individual and population attributes (life history, seasonal variation in density, biomass and production), and on the other hand the efficiency of trophic pathways i.e. how efficiently food materials are passed along these pathways (Benke et al., 1992). The voltinism and the length of nymphal life in aquatic insects are two most critical life history features necessary for the understanding of their functional importance in streams. In particular, these parameters are necessary for secondary production estimates, the development of energy budgets for stream, and for environmental impact assessment (Waters, 1979; Benke, 1984). Secondary production represents a heterotrophic biomass formation and its measurement allows the evaluation of growth and biomass turnover rates, which can improve understanding of the interspecific interactions inside the community and relationships between benthic community and stream habitat (Benke, 1993; Grubaugh et al., 1997; Huryn and Wallace, 2000; Woodcock and Huryn, 2007). Structural and functional changes in macroinvertebrate community are linked to the effect of the tree canopy removal on the energy base of a stream (Kedzierski and Smock, 2001). A conceptual model assumes that the absence of riparian forest significantly increases the quantity of light striking the stream channel and banks, affects the chemistry of water flowing through the riparian zone towards the stream and reduces quantity of allochthonous material in the stream (Sweeney 1993, Cummins et al., 1989; Rowe and Richardson, 2001). These factors in turn affect the amount of primary production, the diversity of microhabitats, temperature and discharge regime, and availability of particulate organic matter for primary consumers (Lyford and Gregory, 1975; Towns, 1981; Tait et al., 1994; Cummins et al., 1989; Higler 1993). Finally, these factors separately and in interaction may influence the functional attributes of individual and population e.g. survivorship, growth, adults size and fecundity, timing of reproduction, abundance, biomass, and, ultimately, the secondary production of each species in the macroinvertebrates community (Sweeney, 1993). In particular, temperature regime and food resources are two of the most important factors governing life history patterns, especially the individual growth rate, seasonal timing of egg and nymphal development and other life history attributes of aquatic insects (Lillehammer, 1975; Hawkins, 1986; Hauer and Benke, 1987; Brittain and Sartori, 2009). On one hand, it is essential to discuss the nutrition together with water temperature. On the other hand, the quality and quantity of food resources are strongly linked to temperature (Van- 
note and Sweeney, 1980; Newbold et al., 1994). The individual growth rate of aquatic insects usually directly reflects water temperature changes. The temperature influences the fecundity, egg incubation period, induction and termination of diapause, duration and success of hatching, which all determine the patterns of distribution and the competitive position of species in given habitat (Ward and Stanford, 1982). Temperature affects the nymphal life span, its duration being inversely proportional to the temperature in most cases (Humpesch, 1984). Riparian deforestation eliminates shading and can result in a $2-5^{\circ} \mathrm{C}$ warming of small streams, which is shown to greatly affect important life history characteristics of macroinvertebrates (Sweeney, 1993; Bilby and Ward, 1991). Knowledge of life histories and emergence periods of aquatic insects (including stoneflies) is fundamental for understanding species biology and behaviour, and also for aquatic conservation purposes (Stazner and Resh, 1993). For example, this knowledge in a specific habitat can help to improve the use and interpretation of biotic indices (Sheldon, 1999). Stonefly nymphs are conspicuous component and essential links in the food webs in running water ecosystems (Hynes, 1970; Stewart and Stark, 1993). Most stonefly species are stenothermic; consequently, variations in thermal regime of watercourses can limit their distribution (Ward, 1985; Quinn and Hickey, 1990) and determine changes in their life history attributes (Brittain, 1983; Brittain et al., 1984; Sweeney and Vannote, 1986; Perry et al., 1987; Lillehammer et al., 1989; Li et al., 2011; Bottová et al., 2013; Krno et al., 2013). In particular, the distributions and life histories of stoneflies can be strongly affected by riparian deforestation (O'Hop et al., 1984; Quinn et al., 1997; Krno, 2000, Krno et al., 2013). Because the changes in abiotic characteristics of the stream arising from catchment area deforestation can affect the structure and function of benthic communities, the aim of the present study was to determine species composition of stonefly assemblages, life history patterns and secondary production of identified stonefly species in two contrasting streams regarding to the forest coverage of their catchments.

\section{METHODS}

\section{Study sites}

The research was carried out in two second-order tributaries in the upper stretch of Prosiečanka River Basin (Chočské Vrchy Mts., West Carpathians, Slovakia) (Fig. 1). The geological substrate of both catchment areas is formed by flysh. Although the streams are similar morphologically (Tab. 1), they differ in the forest cover of their catchments. While the right tributary, site A (coordinates: $\mathrm{N} 49^{\circ} 10^{\prime} 58.0^{\prime \prime}$,

Tab. 1. Abiotic characteristics of the forested stream (site B) and deforested stream (site A).

\begin{tabular}{lcc} 
& Site $\mathrm{A}$ & Site B \\
Max. width $(\mathrm{m})$ & 2 & 2.8 \\
Max. depth $(\mathrm{m})$ & 0.25 & 0.32 \\
\hline Slope $(\% 0)$ & 35 & 46 \\
Max. temperature $\left({ }^{\circ} \mathrm{C}\right)$ & 20.1 & 17.2 \\
\hline $\mathrm{pH}$ & 7.8 & 8.1 \\
$\mathrm{Conductivity}\left(\mu \mathrm{S} \mathrm{m}^{-1}\right)$ & 440 & 260 \\
$\mathrm{PO}_{4}{ }^{3-}\left(\mathrm{mg} \mathrm{L}^{-1}\right)$ & 0.04 & 0.03 \\
$\mathrm{NO}_{3}{ }^{-}\left(\mathrm{mg} \mathrm{L}^{-1}\right)$ & $<2.0$ & $<2.0$ \\
$\mathrm{SO}_{4}{ }^{2-}\left(\mathrm{mg} \mathrm{L}^{-1}\right)$ & 3.8 & 13.3
\end{tabular}

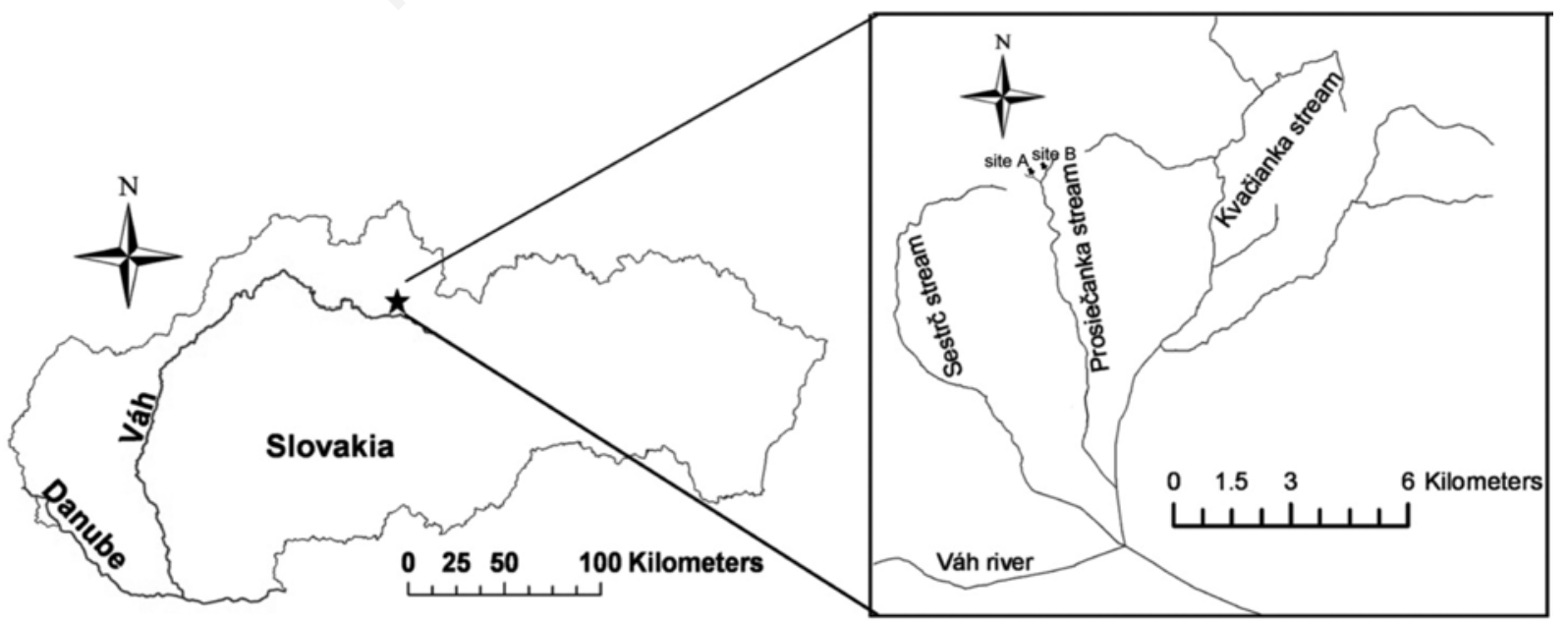

Fig. 1. Map of the study area, showing its location in Slovakia. Black circles represent the position of the sampling sites. 
E $19^{\circ} 29^{\prime} 36.9^{\prime \prime}, 920 \mathrm{~m}$ asl) had $90 \%$ of the catchment deforested and converted to meadows and pastures, the left tributary, site B (coordinates: N 49 $11^{\prime} 04.8^{\prime \prime}$, E 19²8'58.0', $920 \mathrm{~m}$ asl represented a well-preserved submountain stream with $60 \%$ of the catchment covered predominantly by spruce forests. This fact was reflected in the different thermal regime of both streams. The undisturbed site $\mathrm{B}$ had generally lower temperature (mean temperature $=9.7^{\circ} \mathrm{C}$ ) and higher thermal fluctuations $(\mathrm{CV}=50 \%)$ than the disturbed site $\mathrm{A}$ (mean temperature $=13.6^{\circ} \mathrm{C}, \mathrm{CV}=37 \%$ ). The average pair-wise temperature difference was $3.9^{\circ} \mathrm{C}$.

\section{Data collection and processing}

Quantitative samples of the macrozoobenthos were collected monthly, from April to October 2005 using Kubíček's benthic sampler (area $0.1 \mathrm{~m}^{2}$, mesh size $0.5 \mathrm{~mm}$ ). Total sampled area at each site was $0.4 \mathrm{~m}^{2}$ and each sample reflected the following microhabitat scheme: site A, one sample from macrolithal, mesolithal, microlithal and acal; site $\mathrm{B}$, one sample from macrolithal and acal, two samples from mesolithal. Supplementary semi-quantitative samples were taken monthly from mesolithal (1 min), macrolithal, microlithal and acal ( $0.5 \mathrm{~min}$ each) at both sites, with a kick net (mesh size $0.5 \mathrm{~mm}$ ). Collected benthic material was preserved in the field in $4 \%$ formaldehyde. Adults were captured, and preserved in 70\% alcohol, for reconfirming the nymph identification. In the laboratory, stonefly nymphs were separated from detritus and other benthic taxa and identified to the species level using determination keys (Zwick, 2004; Krno, 2013). Water temperature was measured every sampling date with a portable thermometer. Chemical parameters were measured once in October $25^{\text {th }}$, 2007. Water samples were taken to the laboratory where the isotachophoretic determination (Slovak Technical Standard 757430, 1997) was used for detection of $\mathrm{NO}_{3}{ }^{-}$and $\mathrm{SO}_{4}{ }^{2-}$ anions and spectrophotometric determination (Slovak Technical Standard EN ISO 687) was used for detection of $\mathrm{PO}_{4}{ }^{3-}$ anions. The covering of the catchment by forest was estimated using CORINE land cover database in ARGIS 9.3 (ESRI, 2011). Both, quantitative and semi-quantitative samples were used to study life histories. Size-frequency histograms were plotted to assess the life history patterns of the most abundant species. Per month, total body length of each nymph without cerci was measured to the nearest $0.5 \mathrm{~mm}$ with the aid of a micrometer fixed to the binocular microscope. The larvae were sorted into size classes with an interval of $0.5 \mathrm{~mm}$.

Biomass was obtained by using predetermined lengthmass relationships for each species according to Loskutova (2008), Johnston and Cunjak (1999), Benke et al. (1999), Burgherr and Meyer (1997) and expressed as dry mass ( $\mathrm{mg} \mathrm{DW} \mathrm{m}^{-2}$ ). Secondary production was estimated using different methods for abundant and rare species. Annual production of the abundant species was calculated using the size-frequency method (Benke, 1979; Benke and Huryn, 2006). Annual production of the rare species was estimated by multiplying mean annual biomass by annual $\mathrm{P} / \mathrm{B}$ ratio calculated from an empirical equation developed for stonefly species (Leuctra nigra, Leuctra prima, Siphonoperla neglecta) by Krno (1997), Krno and Šporka (2003). Chi-square test was performed to test statistically significant differences in total density, biomass and secondary production of stonefly assemblages between site A and site B.

\section{RESULTS}

\section{Biomass and secondary production}

During the sampling period, a total of 7 species of stoneflies belonging to four families (Nemouridae, Leuctridae, Perlodidae and Perlidae) were recorded at both sites (Tab. 2). Stonefly assemblages of forested stream had much higher species richness (6 species) compared with stonefly assemblages of adjacent deforested stream, where stonefly assemblages consisted only of two species. Nemoura cinerea was eudominant species in both communities and its percentage in forested and deforested stream reached about $80 \%$. In forested stream the percentage contribution of $N$. cinerea to annual community biomass and secondary production equalled to $74.2 \%$ and $65.4 \%$ (Tab. 3), respectively. In deforested stream, these percentage contributions were very similar, reaching $85.5 \%$ (biomass) and $85.8 \%$ (secondary production) (Tab. 4). In forested stream compared to deforested stream, significantly higher (approximately $2 x$ higher $)$ values of total density $(\chi=47.89, \mathrm{P}<0.05)$, total biomass $(\chi=3.69, \mathrm{P}=0.05)$ and annual secondary production $(\chi=23.59, \mathrm{P}<0.05)$ of stoneflies were identified.

\section{Life cycle}

Life-cycle histograms of stoneflies showed that all identified species had univoltine life histories. Detailed life-history information for the species is given below.

Tab. 2. Species composition and species relative abundance of stonefly assemblages in forested stream (site B) and deforested stream (site A).

\begin{tabular}{lcc} 
Species & Site A & Site B \\
Nemoura cinerea Retzius, 1783 & 90.80 & 78.62 \\
Leuctra armata Kempny, 1899 & - & 7.13 \\
\hline Leuctra aurita Navas, 1919 & 9.20 & - \\
Leuctra nigra (Olivier, 1811) & - & 3.67 \\
\hline Leuctra prima Kempny, 1899 & - & 5.83 \\
Arcynopteryx dichroa (Mclachlan, 1872) & - & 2.59 \\
\hline Siphonoperla neglecta (Rostock, 1811) & - & 2.16 \\
\hline
\end{tabular}


Nemoura cinerea showed a univoltine life history with nymphs occurring during all sampling periods (Fig. 2). At the forested site, adult emergence lasted approximately two months (from early April to May) and the first newly hatched nymphs occurred one month after the end of flying period. At the deforested site compared to the forested site, the emergence of $N$. cinerea lasted one month longer and newly hatched nymphs were found one month later. Leuctra aurita was present only in the deforested stream and it exhibited a typical univoltine and synchronous life history (Fig. 3). The newly hatched nymphs were found in early June and emergence period of $L$. aurita was observed for three months, from early April to June. Size frequency distribution of $L$. armata indicated univoltine, autumn-summer life history (Fig. 4). The first hatched nymphs of new generation occurred in October. Flying period of adults started in early June and lasted until early August. L. nigra showed a univoltine life history with hatchling of new generation in late summer and autumn (Fig. 5). Emergence of adults was observed for two months (May-June). Very short and typical autumn/spring life history was found in $L$. prima and Siphonoperla neglecta. L. prima started the cohort life in early September and flying of adults was observed in April and May (Fig. 6). The nymphs of new generation of $S$. neglecta were found at undisturbed site in October and their cohort life lasted until early May, when the last adults were captured (Fig. 7). Typical annual life cycle was noted for Arcynopteryx dichroa (Fig. 8). The newly hatched nymphs were found in early June and emergence period of $A$. dichroa was observed for two months, from May to June.

\section{DISCUSSION}

Riparian organic matter provides an important food source for many benthic invertebrates in small streams, and the differences in allochthonous inputs in terms of theirs quantity and quality have potential for producing changes in the structure of stream communities (Anderson and Sedell, 1979; Cummins and Klug, 1979; Molles, 1982; Webster and Benfield, 1986; Gessner et al., 1999). Removal of riparian vegetation increases solar penetration to the stream channel (Quinn et al., 1997). Consequently, it alters the thermal regime and increases the quantity of autochthonous food resources (Allan, 1995). Deforested river basins also receive more inorganic nutrients, especially inorganic $\mathrm{N}$, from terrestrial sources (Johnson et al., 2007). All these changes influence the trophic structure of benthic communities (Gurtz and Wallace, 1984). In particular, leaves that decompose at different rates and vary in chemical composition are likely to affect rates of growth and production of benthic invertebrates. Because the riparian zones and the catchment areas of both studied streams had very different degree of forest cover, we were interested in how this fact fitted the prediction of the stoneflies response model of Krno (2000, 2009). According to this prediction model the percentage of the deforestation at the catchment level increased the proportion of individuals of the genus Nemoura and decreased the proportion of predaceous stonefly species (Krno, 2000). These statements were also clearly verified in our results, where the predaceous stonefly species were completely absent in non-forested stream and the proportion of nemourids increased up to $90.8 \%$. Several studies have

Tab. 3. Population density, biomass and secondary production of stonefly species at undisturbed tributary (site B) of Prosiek stream.

\begin{tabular}{|c|c|c|c|c|}
\hline Species & $\begin{array}{l}\text { Mean density } \\
\text { (ind. } \mathrm{m}^{-2} \text { ) }\end{array}$ & $\begin{array}{l}\text { Mean biomass } \\
\left(\mathrm{mg} \mathrm{DW} \mathrm{m} \mathrm{m}^{-2} \text { ) }\right.\end{array}$ & $\begin{array}{l}\text { Annual production } \\
\qquad\left(\mathrm{mg} \mathrm{DW} \mathrm{m}^{-2} \text { ) }\right.\end{array}$ & $\mathrm{P} / \mathrm{B}$ ratio \\
\hline Nemoura cinerea & 364 & 17.34 & 82.66 & 4.77 \\
\hline Leuctra armata & 33 & 3.18 & 13.5 & 4.25 \\
\hline Leuctra nigra & 17 & 1.03 & 4.72 & 4.60 \\
\hline Leuctra prima & 27 & 3,86 & 22,42 & 6.54 \\
\hline Arcynopteryx dichroa & 12 & 3,40 & 13.77 & 4.05 \\
\hline Siphonoperla neglecta & 10 & 1.82 & 11.81 & 6.50 \\
\hline Totally & 463 & 23.37 & 126.46 & \\
\hline
\end{tabular}

Tab. 4. Population density, biomass and secondary production of stonefly species at disturbed tributary (site A) of Prosiek stream.

\begin{tabular}{|c|c|c|c|c|}
\hline Species & $\begin{array}{l}\text { Mean density } \\
\text { (ind. } \mathrm{m}^{-2} \text { ) }\end{array}$ & $\begin{array}{l}\text { Mean biomass } \\
\left(\mathrm{mg} \mathrm{DW} \mathrm{m}^{-2} \text { ) }\right.\end{array}$ & $\begin{array}{l}\text { Annual production } \\
\qquad\left(\mathrm{mg} \mathrm{DW} \mathrm{m}^{-2}\right)\end{array}$ & P/B ratio \\
\hline Nemoura cinerea & 237 & 8.22 & 40.67 & 4.95 \\
\hline Leuctra aurita & 24 & 1.39 & 6.72 & 4.84 \\
\hline Totally & 261 & 9.61 & 47.39 & \\
\hline
\end{tabular}


shown that structural and functional features of taxocenoses may be predicted by catchment properties (e.g. Hawkins et al., 1982; Richards et al., 1997; Sponseller et al., 2001). The percentage of forest cover as one of the large-scale catchment characteristic determines species composition and diversity of EPT taxa (Sponseller et al., 2001; Briers and Gee, 2004). Recent results suggest that the community structure of benthic fauna reflects the local land-use disturbances, as well as functional processes at the community level (Sponseller and Benfield, 2001). In our study, observed differences between the disturbed and the undisturbed site were noted at structural level (community composition, species den sity and biomass), as well as functional level (secondary production, life histories in some species). Approximately $2 \mathrm{x}$ higher values of total stonefly abundance, biomass and secondary production were found in undisturbed stream. Bottová et al. (2012) found similar differences in mayfly communities between these streams but values of analyzed mayfly parameters were several times higher. Eisendle and Waringer (1999) found similarly higher values of total mayfly abundance compared to stonefly abundance in small alpine sandstone stream.
The estimated secondary production of both stonefly communities were relatively low compared to the other West Carpathians streams. Krno (2000) determined annual stonefly production in small volcanic stream at 340 mg DW m ${ }^{-2}$ year $^{-1}$. Furthermore, annual stonefly production measured in limestone stream L'ubčianka ranged from $914 \mathrm{mg} \mathrm{DW} \mathrm{m}^{-2}$ year $^{-1}$ to $1318 \mathrm{mg} \mathrm{DW} \mathrm{m}^{-2}$ year $^{-1}$ (Krno, 1997). Extremely high annual stonefly production (4304 mg DW m ${ }^{-2}$ year $^{-1}$ ) was found in karst spring in lower stretch of Prosiečanka River (Bottová et al., 2013). In sandstone streams compared to others, e.g. limestone or granite streams, the lowest values of production are generally recorded (Krueger and Waters, 1983; Šporka and Krno, 2003; Jin and Ward, 2007). According to Krno et al. (2013) changes in water temperature in mountain streams with the lack of riparian cover were sufficient to alter larval recruitment and growth for several stonefly taxa. Similarly, Sweeney (1993) found, that temperature changes about $3-5^{\circ} \mathrm{C}$ in Piedmont streams with the lack of riparian cover were responsible for alternation of larval emergence and growth for several mayfly taxa. In our study, the slight shifts in the life histories (e.g., shifts in

Site A
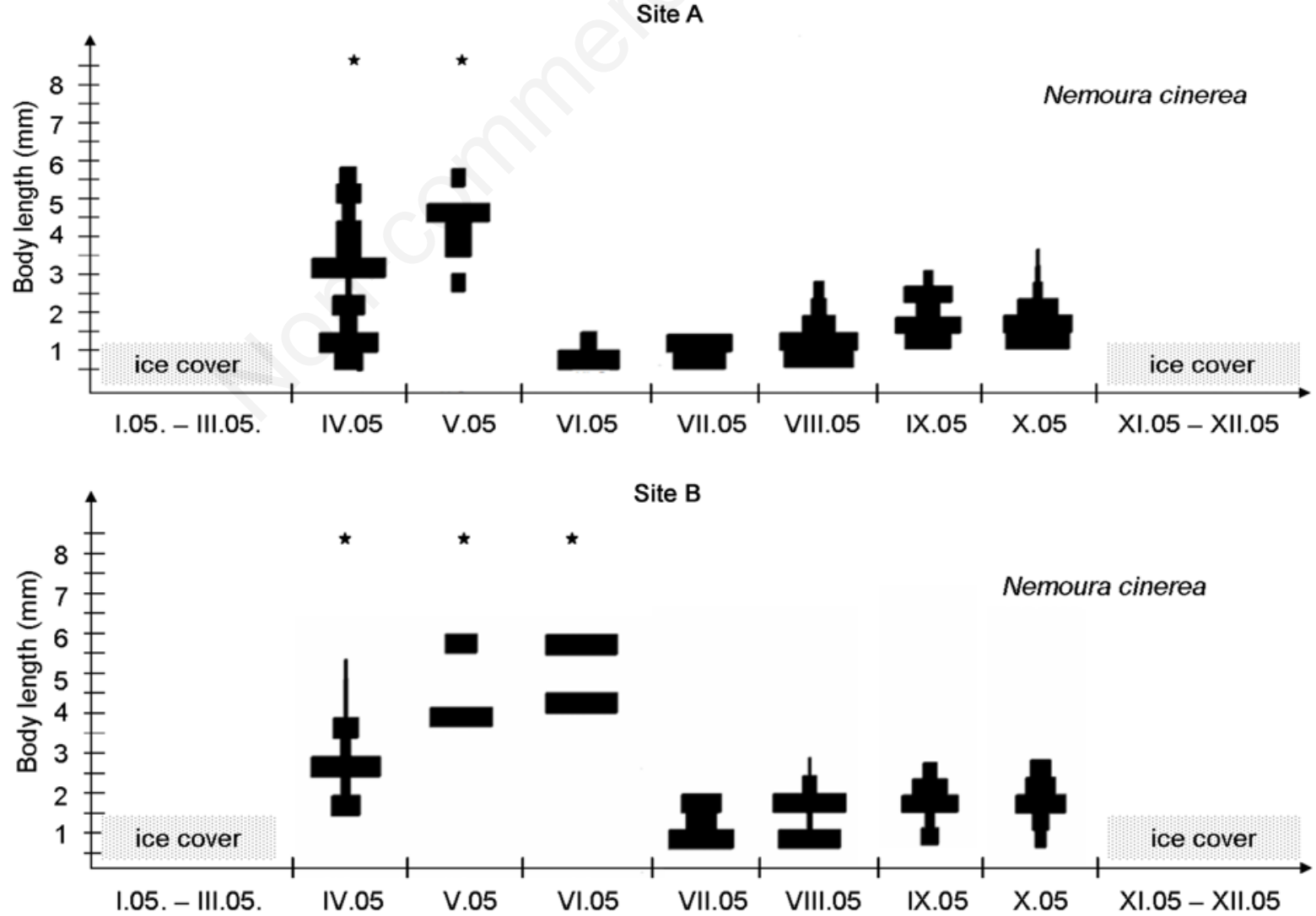

Fig. 2. Size-frequency distribution of Nemoura cinerea at disturbed tributary (site A) of Prosiek stream, Northern Slovakia (April to October 2005) and at undisturbed tributary (site B). Asterisks indicate the presence of the imagines. 


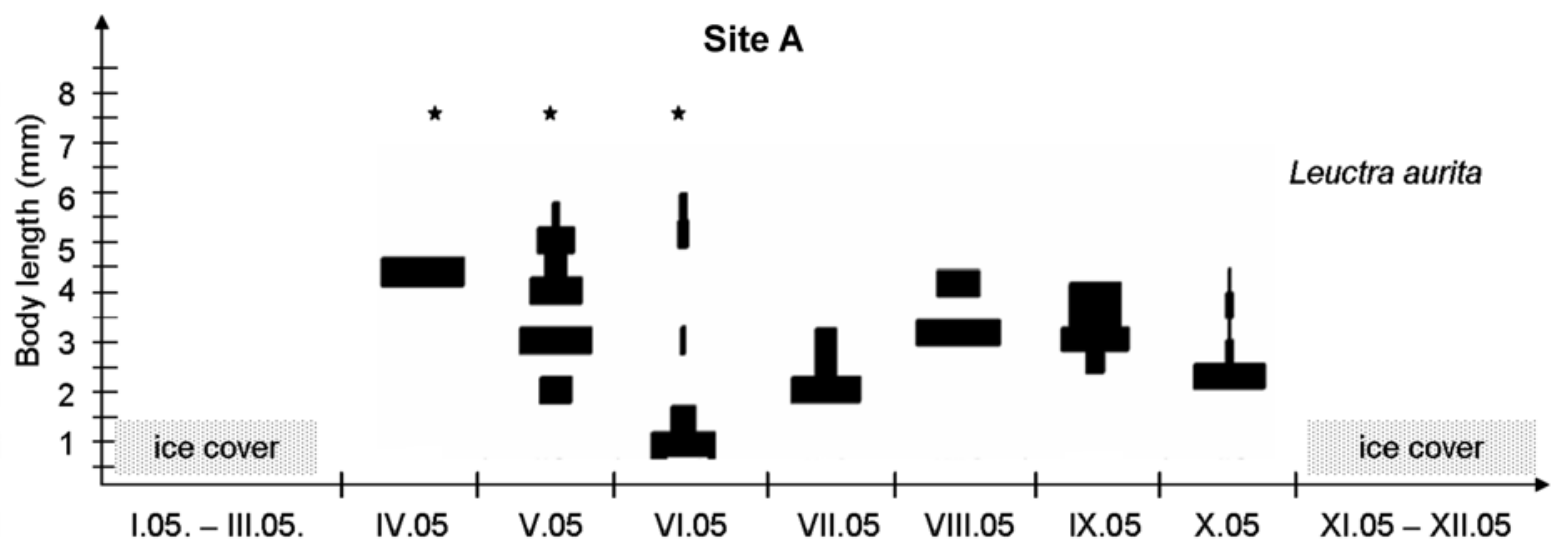

Fig. 3. Size-frequency distribution of Leuctra aurita at disturbed tributary (site A) of Prosiek stream, Northern Slovakia (April to October 2005). Asterisks indicate the presence of the imagines.

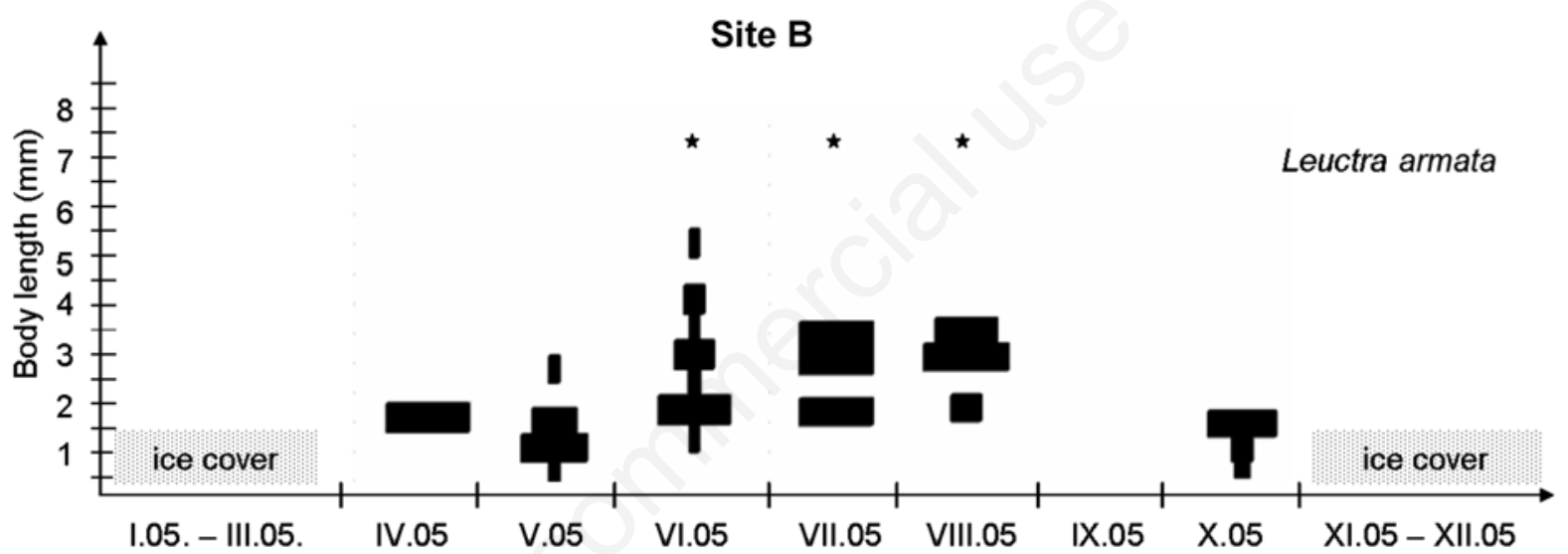

Fig. 4. Size-frequency distribution of Leuctra armata at undisturbed tributary (site B) of Prosiek stream, Northern Slovakia (April to October 2005). Asterisks indicate the presence of the imagines.

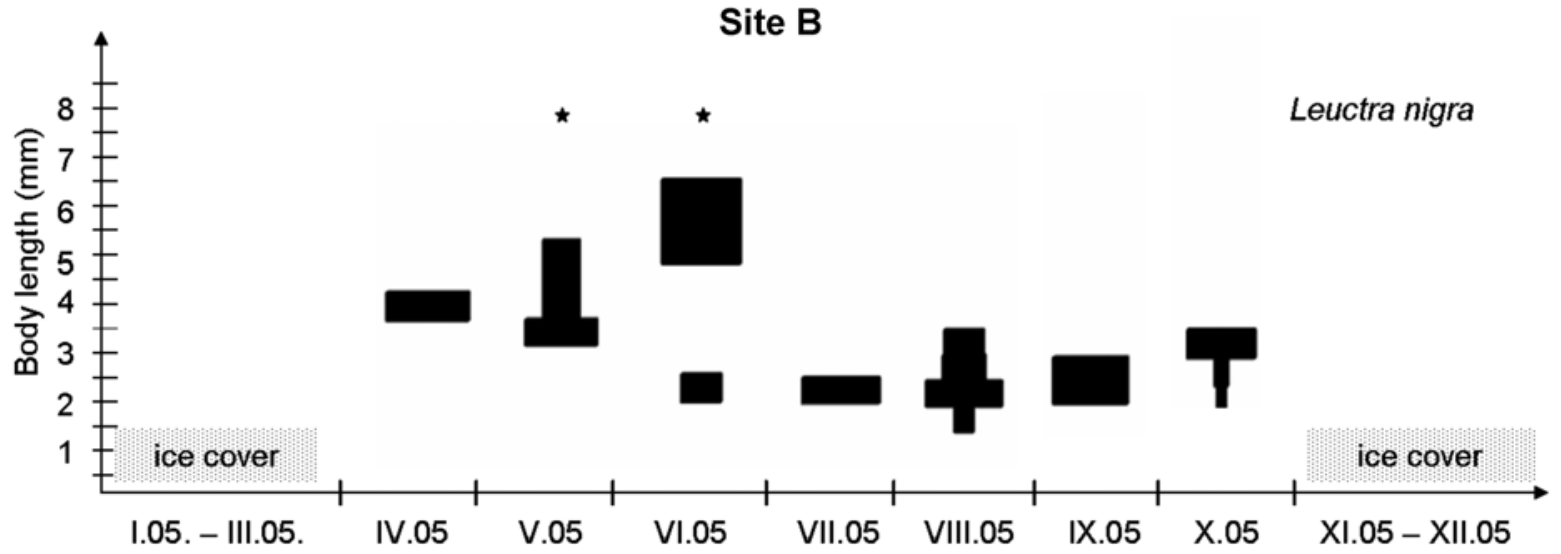

Fig. 5. Size-frequency distribution of Leuctra nigra at undisturbed tributary (site B) of Prosiek stream, Northern Slovakia (April to October 2005). Asterisks indicate the presence of the imagines. 


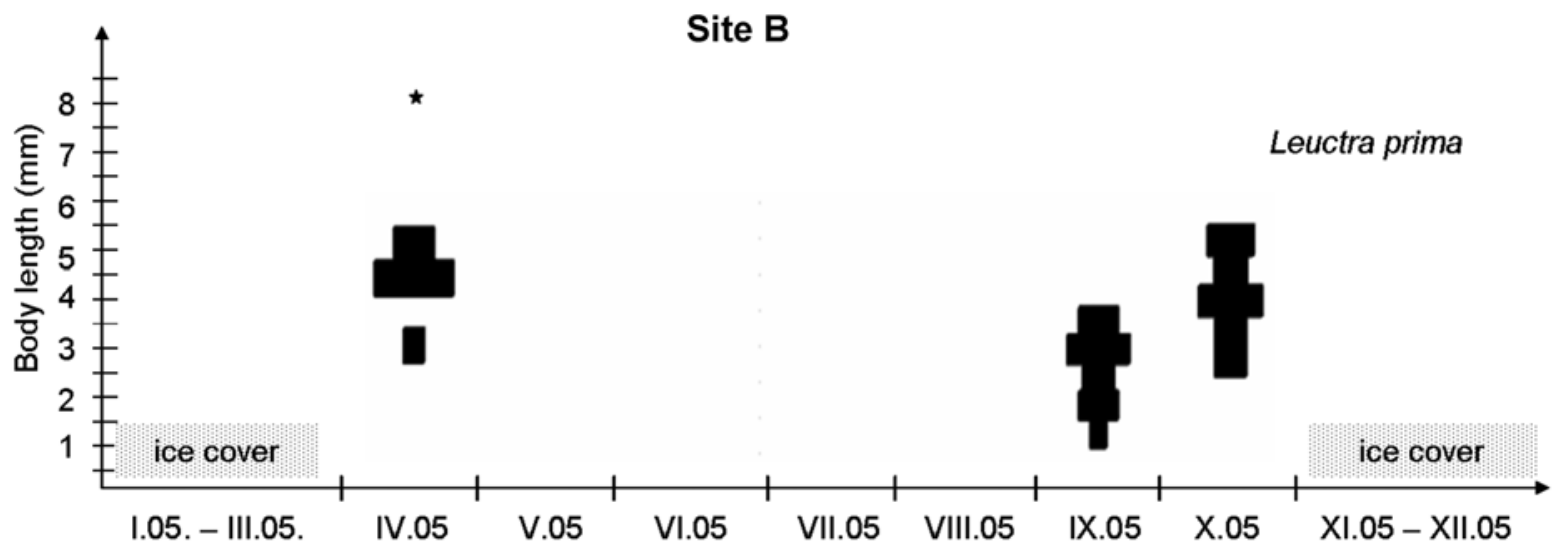

Fig. 6. Size-frequency distribution of Leuctra prima at undisturbed tributary (site B) of Prosiek stream, Northern Slovakia (April to October 2005). Asterisks indicate the presence of the imagines.

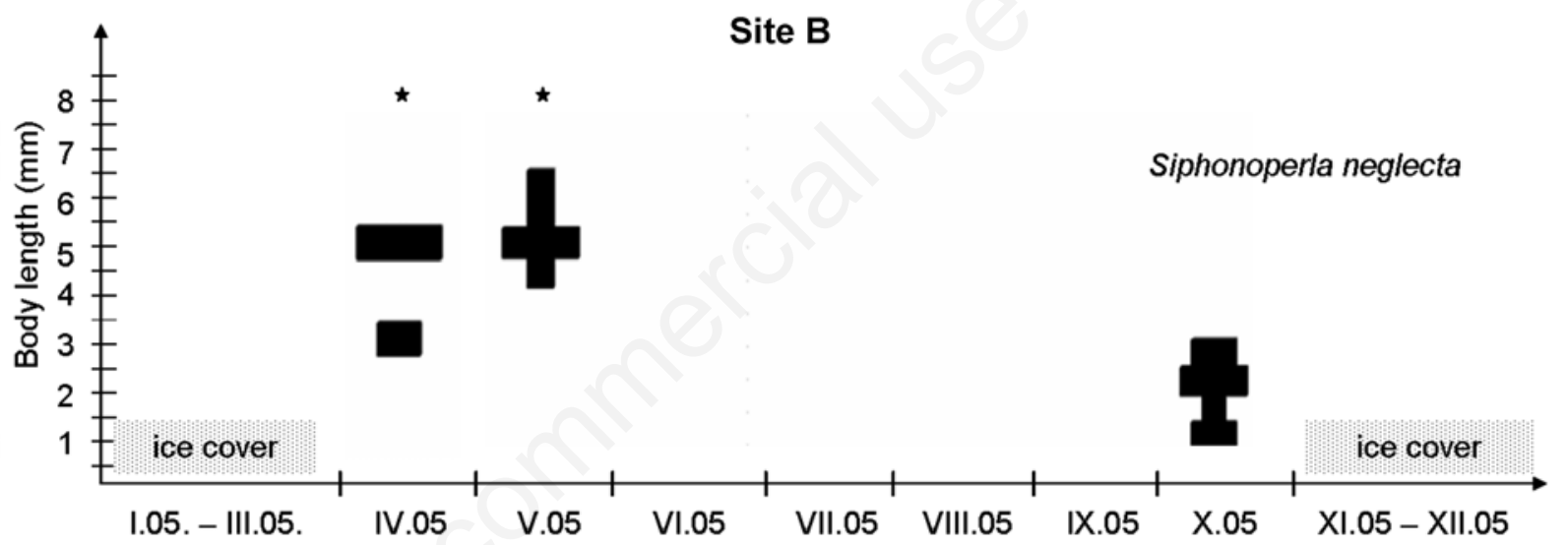

Fig. 7. Size-frequency distribution of Siphonoperla neglecta at undisturbed tributary (site B) of Prosiek stream, Northern Slovakia (April to October 2005). Asterisks indicate the presence of the imagines.

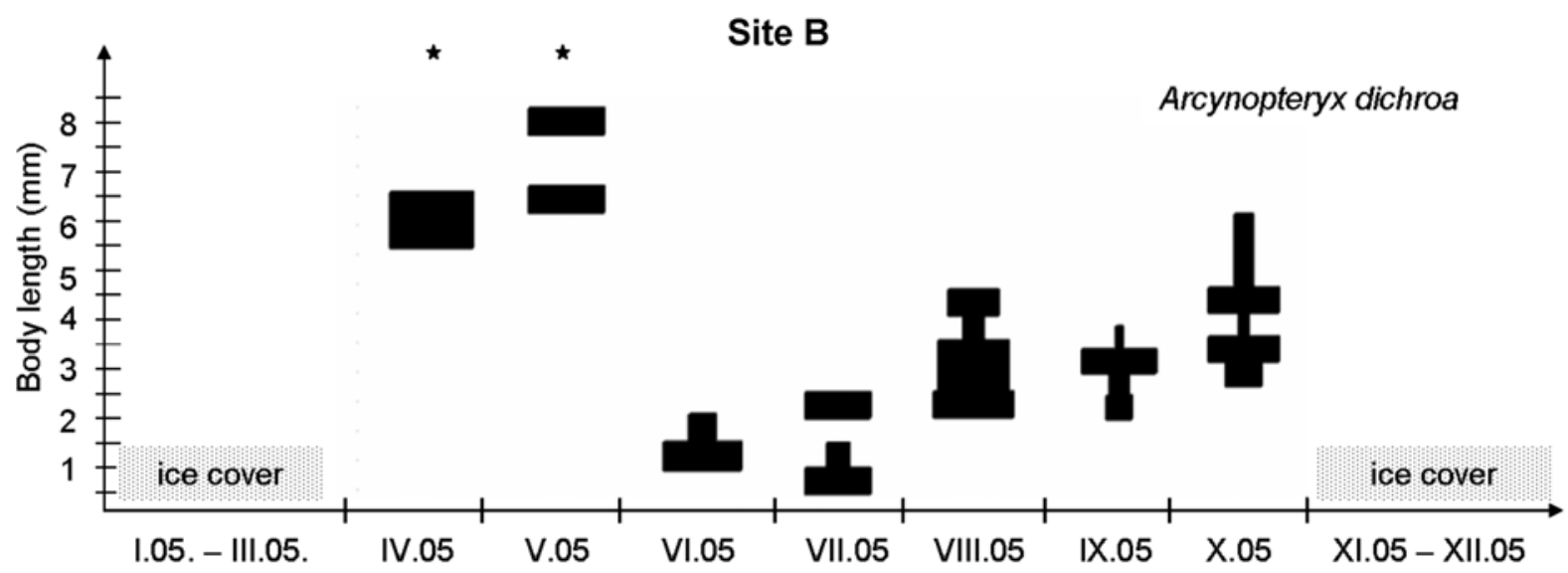

Fig. 8. Size-frequency distribution of Arcynopteryx dichroa at undisturbed tributary (site B) of Prosiek stream, Northern Slovakia (April to October 2005). Asterisks indicate the presence of the imagines. 
later larvae hatching and emergence of adults at the undisturbed site for $N$. cinerea) were probably associated with different regimes of water temperatures. $N$. cinerea is one of the most tolerant and widespread stonefly species in running water (Brittain, 1991; Malmqvist, 1999). Plasticity in life cycle and asynchrony in egg development enables this species to inhabit a wide range of freshwater habitats (Brittain and Lillehammer, 1987). The life cycle of $N$. cinerea is frequently described as a univoltine with slow individual growth during the winter period (Benedetto, 1973; Pretty et al., 2005). In Carpathian streams, $N$. cinerea has univoltine life cycle with an overwintering generation and the flight period from April to August (Krno, 2004) and this corresponds to our results. Compared to $\mathrm{P} / \mathrm{B}$ ratio value $(\mathrm{P} / \mathrm{B}=4.2)$ determined by Krno (1998), we estimated slightly higher values of annual turnover biomass for this species. Two times higher value of annual secondary production in the undisturbed stream in comparison with the disturbed stream is suggesting the species preference for pristine conditions. Production values for this species were similar as Krno (1998) and Pretty et al. (2005) found in an acid streams.

L. aurita belongs to euryoecous and mesothermophilous stonefly species in the Western Carpathian streams (Krno, 2000; Krno and Žiak, 2012). For this species, Krno (1982, 1997, 2000) determined a univoltine life cycle with fast summer development (CPI=125-170) in mountain streams. In our study, L. aurita exhibited a typical annual univoltine life cycle with flying period from April to early June. Annual production was similarly low as it was found by Krno $(1997,2000)$. L. armata inhabits crenal and epirhithral stretch of Central-European streams (Fochetti and Tierno de Figueroa, 2004; Graf et al., 2009). It is a typical univoltine species with slow life cycle, with nymphs growing almost all the year) (Krno, 1982; Krno and Šporka, 2003). Flight period extends from the end of spring to the beginning of autumn, but occurs mainly in summer (Illies, 1955; Fochetti and Tierno de Figueroa, 2008; Graf et al., 2009). Our estimated annual secondary production $\left(13.5 \mathrm{mg} \mathrm{DW} \mathrm{m}^{-2}\right)$ was ten times lower than it was in karst spring of Prosiečanka River (Bottová et al., 2013), but very similar as Krno (1997) found in granite section of Carpathian mountain stream (18 $\mathrm{mg} \mathrm{DW} \mathrm{m}^{-2}$ ).

L. nigra is euryecous species, inhabiting hyporhithral to eucrenal zones of Carpathian streams (Krno, 1982; Šporka et al., 2003). For this species, a typical semivoltine life cycle can change to univoltine with increasing water temperature (critical water temperature is about $15^{\circ} \mathrm{C}$ ) (Elliott, 1987). In L. nigra, the univoltine life cycle was associated with lower larvae survival and egg production (Elliott, 1987). These statements fully correspond with our results, that the temperature regime of studied stream probably causes univoltine life cycle in L. nigra.
L. prima belongs to Central-European stonefly species reaching the south Pyrenees, Macedonia and Northern Italy (Fochetti and Tierno de Figueroa, 2004). It is eurythermophilous species inhabiting different types of lotic biotopes in a large scale of altitude but it prefers epirhithral and metarhitral zone of streams (Krno, 2007; Graf et al., 2009). It is generally known, that L. prima has a univoltine life cycle with spring flight period (Illies, 1955; Krno, 1982, 1998; Zwick, 1990; Fochetti and Tierno de Figueroa, 2008; Graf et al., 2009) although Bottová et al. (2013) identified unusual bivoltine life cycle for this species in karst spring only few kilometers lower, below our studied sites. In L. prima, we noted a typical life cycle with spring imagines occurrence and summer diapause. The fast winter-spring development, values of secondary production and turnover biomass were very similar as Krno (1998) recorded for this species in mountain section of sandstone Carpathian stream.

Oligostenothermal species Siphonoperla neglecta has montane distribution in the Western Carpathians, where it inhabits mainly springs and small brooks (Krno, 2000). It is a species with univoltine life cycle (Krno and Šporka, 2003; Graf et al., 2009) and flight period in spring (Krno, 1982; Krno and Šporka, 2003) coinciding with our findings. The low annual secondary production of $S$. neglecta (3,7 $\mathrm{mg} \mathrm{DW} \mathrm{m}^{-2}$ ) estimated by Krno and Šporka (2003) in West Carpathians, fully corresponds with our results.

Very little is known about the life cycle and secondary production of Arcynopteryx dichroa. According to Theissinger et al. (2013), it is a glacial relict that survived glacial cycles through altitudinal shifts in isolated periglacial populations in the Pyrenees, the central European highlands, the Carpathians, the Balkans and the eastern Alps. This species with arctic-alpine disjunct distribution is generally considered cold-adapted, typically inhabiting springs and spring-fed brooks of high elevations (Graf et al., 1995). It is a relatively large predator of other benthic organisms (Lillehammer, 1974). Similar univoltine pattern of life cycle with larval development from early summer to later spring was also found in the northern Urals (Loskutova, 2008). In Fennoscandia, $A$. dichroa had semivoltinne two-year life cycle with egg diapause in the first winter and hatching in the following spring (Lillehammer, 1988). Our estimate of $\mathrm{P} / \mathrm{B}$ ratio was slightly lower as Loskutova (2008) found for this species in the mountain section of the Shugor River but these values fully correspond to the theoretical values for benthic organisms with one year development (Benke, 1984).

\section{CONCLUSIONS}

Our results reflect the well-known fact that the stream side canopy, especially in small streams, has a substantial effect on the thermal regime of streams. Differences in thermal regimes of streams may also play significant role in 
producing different taxonomic patterns of macroinvertebrate assemblages. Comparison between forest and meadow stream suggests that the change of thermal regime caused by deforestation, even at a very local scale, can alter the species composition of stonefly assemblages, reduce their species diversity and eliminate the most sensitive stonefly taxa. Differences in the forest cover and in the thermal regime of both studied streams were also reflected in the functional level of stonefly assemblages. At the undisturbed site, the total density, biomass and secondary production of stonefly community were significantly higher than at the disturbed site. In general, total macroinvertebrate abundance and biomass have often been increased in streams where canopy cover has been reduced by forest clearing, in large part due to the increased primary production. Most of stonefly taxa are especially sensitive to higher water temperature therefore, it is not surprising that we did not find similar trend in stonefly.

\section{ACKNOWLEDGEMENTS}

The research was supported by the Slovak Grant Agency VEGA project No. 1/0176/12 and 1/0255/15.

\section{REFERENCES}

Allan JD, 1995 Stream ecology. Structure and function of running waters. Chapman \& Hall, New York: 388 pp.

Anderson NH, Sedell JR, 1979. Detritus processing by macroinvertebrates in stream ecosystems. Annu. Rev. Entomol. 24: 351-377.

Benedetto LA, 1973. Growth of stonefly nymphs in Swedish Lapland. Ent. Tidskr. 94:15-19.

Benke AC, 1979. A modification of the Hynes method for estimating secondary production with particular significant for multivoltine population. Limnol. Oceanogr. 24:168-174.

Benke AC, 1993. Concepts and patterns of invertebrate production in running waters. Verh. Int. Verein. Limnol. 25:15-38.

Benke AC, 1984. Secondary production of aquatic insects, p. 289-323. In: V. H. Resh and D. M. Rosenberg (eds.), Ecology of aquatic insects. Prager Publisher.

Benke AC, Hauer FR, Stites DL, Meyer JL, Edwards, RT, 1992. Growth of snag-dwelling mayflies in a blackwater river: the influence of temperature and food. Arch. Hydrobiol. 125:63-81.

Benke AC, Huryn AD, Smock LA, Wallace JB, 1999. Lengthmass relationships for freshwater macroinvertebrates in North America with particular reference to the southeastern United States. J. N. Am. Benthol. Soc. 18:308-343.

Benke AC, Huryn AD, 2006. Secondary production of macroinvertebrates, p. 691-710. In: F.R. Hauer and G.A. Lamberti, (eds.), Methods in Stream Ecology: 2nd ed. Academic Press.

Bilby RE, Ward JW, 1991. Changes in characteristics and function of woody debris with increasing size of streams in western Washington. Trans. Amer. Fish. Soc. 118:368-378.

Bottová K, Derka T, Svitok M, 2012. Life history and secondary production of mayflies (Ephemeroptera) indicate disturbance in two small Carpathian streams. Int. Rev. Hydrobiol. 97:100-116.
Bottová K, Derka T, Beracko P, Tierno de Figueroa JM, 2013. Life cycle, feeding and secondary production of Plecoptera community in a constant temperature stream in Central Europe. Limnologica 43:27-33.

Briers RA, Gee JHR, 2004. Riparian forestry management and adult stream insects. Hydrol. Earth Syst. Sc. 8:545-549.

Brittain, JE, 1991. Life history characteristics as a determinand of the response of mayflies and stoneflies to man-made environmental disturbance (Ephemeroptera and Plecoptera), p. 539-545. In: J. Alba-Tercedor and A. Sanchez-Ortega (eds.), Overview of strategies of Ephemeroptera and Plecoptera. Sandhill Crane Press.

Brittain JE, 1983. The influence of temperature on nymphal growth rates in mountain stoneflies (Plecoptera). Ecology 64:440-446.

Brittain JE, Lillehammer A, Bildeng R, 1984. The impact of a water transfer scheme on the benthic macroinvertebrates of a Norwegian river, p. 189-199. In: A. Lillehammer and S.J. Saltveit (eds.), Regulated rivers. University of Oslo Press, Oslo.

Brittain JE, Lillehammer A, 1987. Variability in the rate of egg development of the stonefly, Nemoura cinerea (Plecoptera). Freshwater Biol. 17:565-568.

Brittain JE, Sartori M, 2009. Ephemeroptera: (Mayflies), p. 328334. In: V. Resh and R. Carde (eds.), Encyclopedia of insects, 2nd ed. Academic Press.

Burgherr P, Meyer E, 1997. Regression analysis of linear body dimensions vs. dry mass in stream macroinvertebrates. Arch. Hydrobiol. 139:101-112.

Covich AP, Palmer MA, Crowl TA, 1999. The role of benthic invertebrate species in freshwater ecosystems: zoobenthic species influence energy flows and nutrient cycling. BioScience 49:119-127.

Cummins KW, Klug MJ, 1979. Feeding ecology of stream invertebrates. Ann. Rev. Ecol. Syst. 10:147-172.

Cummins KW, Wilzbach MA, Gates DM, Perry JB, Taliaferro WB, 1989. Shredders and riparian vegetation. Bioscience 39:24-30.

Eisendle U, Waringer J, 1999: Faunistik und Phaenologie der Ephemeroptera, Plecoptera und Trichoptera eines FlyschWienerwaldbaches (Weidlingbach, Niederoesterreich) / Phenology of mayflies, stoneflies and caddisflies in a small sandstone brook of the Wienerwald area (Weidlingbach, Niederoesterreich). Lauterbornia 35:21-31.

Elliott JM, 1987. Temperature-induced changes in the life cycle of Leuctra nigra (Plecoptera:Leuctridae) from a Lake District stream. Freshwater Biol. 18:177-184.

ESRI, 2011. ArcGIS Desktop: Release10. Environmental Systems Reseaech Institute, Redlands.

Fochetti R, Tierno de Figueroa JM, 2004. Plecoptera. Available from: www.faunaeur.org

Fochetti R, Tierno de Figueroa JM, 2008. Global diversity of stoneflies (Plecoptera; insecta) in freshwater. In E.V. Balian, C. Lévêque, H. Segers and K. Martens (eds.), Freshwater animal diversity assessment. Hydrobiologia 595:265-377.

Gessner MO, Chauvet E, Dobson MA, 1999. Perspective on leaf litter breakdown in stream. Oikos 85:377-384.

Graf W, Grasser U, Weinzierl A, 1995. [Plecoptera], pp. 1-76. In: O. Moog (ed.), [Fauna aquatica Austriaca].[Book in German]. Bundesministerium für Land- und Forstwirtschaft. 
Graf W, Lorenz AW, Tierno de Figueroa JM, Lücke S, LopezRodriguez MJ, Davies C, 2009. Distribution and ecological preferences of European freshwater organisms. 2. Plecoptera. Sofia, Moscow: 262 pp.

Grubaugh JW, Wallace JB, Houston ES, 1997. Production of benthic macroinvertebrate communities along a southern Appalachian river continuum. Freshwater Biol. 37:581-596.

Gurtz ME, Wallace JB, 1984. Substrate-mediated response of stream invertebrates to disturbance. Ecology 65:1556-1569.

Hauer FR, Benke AC, 1987. Influence of temperature and river hydrograph on black fly growth rates in a subtropical blackwater river. J. N. Am. Benthol. Soc. 6:251-261.

Hawkins CP, 1986. Variation in individual growth rates and population densities of ephemerellid mayflies. Ecology 76 : 1384-1395.

Hawkins CP, Murphy ML, Anderson NH, 1982. Effects of canopy, substrate composition, and gradient on the structure of macroinvertebrate communities in cascade range streams of Oregon. Ecology 63:1840-1856.

Higler LWG, 1993. The riparian community of north-west European lowland streams. Freshwater Biol. 29:229-241.

Humpesch UH, 1984. Egg development of non-diapausing exopterygote aquatic insects occurring in Europe. Österr. Akad. Wissensch.193:329-341.

Huryn AD, Wallace JB, 2000. Life history and production of stream insects. Annu. Rev. Entomol. 45:83-110.

Hynes HBN, 1970. The ecology of running waters. Univ. Toronto Press, Toronto: $555 \mathrm{pp}$.

Illies J, 1955. [Steinfliegen order Plecoptera], pp. 155. In: G. Veb (ed.), [Die Tierwelt Deutschlands und der angrenzenden Meeresteile].[Book in German]. Fisher Verlag.

Jin HS, Ward GM, 2007. Life history and secondary production of Glossosoma nigrior (Trichoptera: Glossosomatidae) in two Alabama streams with different geology. Hydrobiologia 575:245-258.

Johnston TA, Cunjak RA, 1999. Dry mass-length relationships for benthic insects: a review with new data from Catamaran Brook, New Brunswick, Canada. Freshwater Biol. 41:653-674.

Johnson RE, Tuchman NC, Peterson CG, 1997. Changes in the vertical microdistribution of diatoms within a developing periphyton mat. J. N. Am. Benthol. Soc. 16:503-519.

Kedzierski WM, Smock LA, 2001. Effects of logging on macroinvertebrate production in a sand-bottomed, low-gradient stream. Freshwater Biol. 46:821-833.

Krno I, 1982. [Štruktura a dynamika makrozoobentosu riečky L'upčianky a jej pritokov (Nizke Tatry)].[Article in Slovak]. Biologické Práce (Bratislava) 28:1-126.

Krno I, 1997. Production and distribution of stoneflies of Slovakia, pp. 199-204. In: P. Lanoldt and M. Sartori (eds.), Ephemeroptera and Plecoptera: biology-ecology-systematics. Mauron+Tinguely \& Lachat SA, Fribourg.

Krno I, 1998. Influence of abiotic and biotic factors on the life cycles and production of stoneflies (Plecoptera) in an acidified spring area. Biologia 53:195-204.

Krno I, 2000. Stoneflies (Plecoptera) in some volcanic mountain ranges of the West Carpathians (Slovakia) and the impact of human activities. Limnologica 30:341-350.

Krno I, 2004. Nemouridae (Plecoptera) of Slovakia: Autecology and distribution, morphology of nymphs. Entomol. Probl. 34:125-138.
Krno I, 2007: Impact of human activities on stonefly (Insecta:Plecoptera) ecological metrics in the Hron River (Slovakia). Biologia 62:446-457.

Krno I, 2009. [Vplyv využitia krajiny na makro- a mikrodistribúciu pošvatiek podhorských tokov povodia horného Váhu], p. 150-155].[Article in Slovak]. In: L. Kröpfelová and J. Šulcová (eds.), Proceedings $15^{\text {th }}$ Conf. ČLS and SLS, Třeboň.

Krno I, 2013. [Determinačný klúč pre hydrobiológov. Čast' II. Pošvatky (Plecoptera)].Book in Slovak]. Výskumný ústav vodného hospodárstva, Bratislava: 64 pp.

Krno I, Šporka F, 2003. Influence of environmental factors on production of stoneflies (Plecoptera) from the Hincov brook (High Tatra, Slovakia). Ecohydrol. Hydrobiol. 3:409-416.

Krno I, Šporka F, Štefková E, 2013. The influence of environmental variables on larval growth of stoneflies (Plecoptera) in natural and deforested streams. Biologia 68:950-960.

Krno I, Žiak M, 2012. Macrodistributions and microdistributions of stoneflies of calcareous submontane rivers of the West Carpathians, with different land cover. Aquat. Insect. 34:65-84.

Krueger CC, Waters TF, 1983. Annual production of macroinvertebrates in three streams of different water quality. Ecology 64:840-850.

Li JJ, Johnson SL, Sobota JB, 2011. Three responses to small changes in stream temperature by autumn- emerging aquatic insects. J.N. Am. Benthol. Soc. 30:474-484.

Lillehammer A, 1974. Norwegian stoneflies. II. Distribution and relationship to the environment. Norsk Entomological Tidsskrift 21:195-250.

Lillehammer A, 1975. Norwegian stoneflies. III. Field studies on ecological factors influencing distribution. Norw. J. Ent. 22:71-80.

Lillehammer A, 1988. Plecoptera Fauna of Fennoscandia and Denmark. Fauna Entomol. Scand. 21. Brill/Scandinavian Science Press Ltd., Leiden: 163 pp.

Lillehammer A, Brittain JE, Saltveit SJ, Nielsen PS, 1989. Egg development, nymphal growth and life cycle strategies in Plecoptera. Holarctic Ecol. 12/2:173-186.

Loskutova O, 2008. Life cycles, growth and production of stonefly populations, p. 61-77. In: F.R. Hauer, J.A. Stanford and R.L. Newell (eds.), International advances in the ecology, zoogeography, and systematics of mayflies and stoneflies. University of California Press.

Lyford JH, Gregory SV, 1975. The dynamics and structure of periphyton communities in three Cascade mountain streams. Verh. Int. Verein. Theor. Angew. Limnol. 19:1610-1616.

Malmqvist B, 1999: Lotic stoneflies (Plecoptera) in northern Sweden: patterns iín species richness and assemblage structure, p. 63-72. In: N. Friberg and J.D. Carl (eds.), Biodiversity in benthic ecology. Proceedings Nordic Benthological Meeting, Silkeborg.

Molles MC, 1982: Trichopteran communities of streams associated with aspen and conifer forests: Iong-term structural change. Ecology 63:1-6.

Newbold JD, Sweeney BW, Vannote RL, 1994. A model for seasonal synchrony instream mayflies. J. N. Am. Benthol. Soc. 13:3-18.

O’Hop J, Wallace JB, Haefner JD, 1984. Production of a stream shredder, Peltoperla maria (Plecoptera:Peltoperlidae) in dis- 
turbed and undisturbed hardwood catchments. Freshwater Biol. 14:13-21.

Perry WB, Benfield EF, Perry SA, Webster JR, 1987. Energetics, growth, and production of a benthic insect assemblage in a neotropical stream. J. N. Am. Benthol. Soc. 17:443-463.

Pretty JL, Giberson DJ, Dobson M, 2005. Resourcedy namics and detritivore production in an acid stream. Freshwater Biol. 50:578-591.

Quinn JM, Hickey CW, 1990. Characterisation and classification of benthic invertebrate communities in 88 New Zealand rivers in relation to environmental factors. New Zeal. J. Mar. Fresh. 24:387-410.

Quinn JM, Cooper AB, Davies-Colley RJ, Rutherford JC, Williamson RB, 1997. Land use effects on habitat, water quality, periphyton, and benthic invertebrates in Waikato, New Zealand hill-country streams. New Zeal. J. Mar. Fresh. 31:579-597.

Quinn JM, Croker GF, Smith BJ, Bellingham MA, 2009. Integrated catchment management effects on flow, habitat, instream vegetation and macroinvertebrates in Waikato, New Zealand, hill-country streams. New Zeal. J. Mar. Fresh. 43: 775-802.

Richards C, Haro RJ, Johnson LB, Host GE, 1997. Catchment and reach-scale properties as indicators of macroinvertebrate species traits. Freshwater Biol. 37:219-230.

Rowe L, Richardson JS, 2001. Community responses to experimental food depletion: resource tracking by stream invertebrates. Oecologia 129:473-480.

Sheldon AL, 1999. Emergence patterns of large stoneflies (Plecoptera:Pteronarcys Calineuria, Hesperoperla) in a Montana river. Great Basin Nat. 59:169-174.

Sponseller R, Benfield EF, 2001. Influence of land use on leaf breakdown in southern Appalachian headwater streams: multiple scale analysis J. N. Am. Benthol. Soc. 20:44-59.

Sponseller RA, Benfield EF, Valett HM, 2001. Relationships between land use, spatial scale and stream macroinvertebrate communities. Freshwater Biol. 46:1409-1424.

Statzner B, Resh VH, 1993. Multiple-site and -year analyses of stream insect emergence: a test of ecological theory. Oecologia 96:65-79.

Stewart KW, Stark BP, 1993. Nymphs of North American stonefly genera (Plecoptera). University of North Texas Press, Denton: $460 \mathrm{pp}$.

Sweeney BW, 1993. Effects of streamside vegetation on macroinvertebrate communities of White Clay Creek in eastern North America. P. Acad. Nat. Sci. Phila. 144: 291-340.

Sweeney BW, Vannote RL, 1986. Growth and production of a stream stonefly: influences of diet and temperature. Ecology 67:1396-1410.

Šporka F, Krno I, 2003. Benthic invertebrates and metabolism of West Carpathian (Slovakia) rivers. Int. Rev. Hydrobiol. 88:274-283.

Šporka F, Bitušík P, Bulánková E, Cséfalvay R, Čejka T, Derka T, Elexová E, Halgoš J, Hamerlík L, Illešová D, Jäch MA, Kodada J, Košel V, Krno I, Novikmec M, Zat'ovičová Z, 2003. Vodné bezstavovovce (makroevertebráta) Slovenska. [Súpis druhov a autekologické charakteristiky[Book inSlovak].. Slovenský hydrometeorologický ústav, Bratislava: 590 pp.

Tait CK, Li JL, Lamberti GA, Pearsons TN, Li HW, 1994. Relationships between riparian cover and the community structure of high desert streams. J. N. Am. Benthol. Soc. 13:45-56.

Theissinger K, Bálint M, Feldheim KA, Haase P, Johannesen J, Laube I, Pauls SU, 2013. Glacial survival and post-glacial recolonization of an arctic-alpine freshwater insect (Arcynopteryx dichroa, Plecoptera, Perlodidae) in Europe. J. Biogeogr. 40:236-248.

Towns DR, 1981. Life histories of benthic invertebrates in a kauri forest stream in northern New Zealand. Aust. J. Mar. Fresh. Res. 32:191-211.

Vannote RL, Sweeney BW, 1980. Geographic analysis of thermal equilibria: A conceptual model for evaluating the effect of natural and modified thermal regimes on aquatic insect communities. Am. Nat.115:667-695.

Wallace JB, Webster JR, 1996. The role of macroinvertebrates in stream ecosystem function. Annu. Rev. Entomol. 41:115-139.

Ward JV, 1985. Thermal characteristics of running waters. Hydrobiologia 125:31-46.

Ward JV, Stanford JA, 1982. Thermal responses in the evolutionary ecology of aquatic insects. Annu. Rev. Entomol. 27:97-117.

Waters TF, 1979. Influence of benthos life history upon the estimation of secondary production. J. Fish. Res. Board Can. 36:1425-1430.

Webster JR, Benfield EF, 1986. Vascular plant breakdown in freshwater ecosystems. Annu. Rev. Ecol. Syst. 17:567-94.

Woodcock TS, Huryn AD, 2007. The response of macroinvertebrate production to a pollution gradient in a headwater stream. Freshwater Biol. 52:177-196.

Zwick P, 1990. Emergence, maturation and upstream oviposition flights of Plecoptera from the Breitenbach, with notes on the adult phase as a possible controlof stream insect populations. Hydrobiologia 194:207-223.

Zwick P, 2004. Key to the West Palaearctic genera of stoneflies (Plecoptera) in the larval stage. Limnology 34:315-348. 